\title{
Front Matter: Volume 9595
}

, "Front Matter: Volume 9595," Proc. SPIE 9595, Radiation Detectors: Systems and Applications XVI, 959501 (27 August 2015); doi: $10.1117 / 12.2218088$

SPIE Event: SPIE Optical Engineering + Applications, 2015, San Diego, California, SPIE. United States 


\section{PROCEEDINGS OF SPIE}

\section{Radiation Detectors: Systems and Applications XVI}

Gary P. Grim

H. Bradford Barber

Editors

12 August 2015

San Diego, California, United States

Sponsored and Published by

SPIE 
The papers in this volume were part of the technical conference cited on the cover and title page. Papers were selected and subject to review by the editors and conference program committee. Some conference presentations may not be available for publication. Additional papers and presentation recordings may be available online in the SPIE Digital Library at SPIEDigitallibrary.org.

The papers reflect the work and thoughts of the authors and are published herein as submitted. The publisher is not responsible for the validity of the information or for any outcomes resulting from reliance thereon.

Please use the following format to cite material from these proceedings:

Author(s), "Title of Paper," in Radiation Detectors: Systems and Applications XVI, edited by Gary P. Grim, H. Bradford Barber, Proceedings of SPIE Vol. 9595 (SPIE, Bellingham, WA, 2015) Sixdigit Article CID Number.

ISSN: 0277-786X

ISSN:1996-756X (electronic)

ISBN: 9781628417616

Published by

SPIE

P.O. Box 10, Bellingham, Washington 98227-0010 USA

Telephone +1 3606763290 (Pacific Time) · Fax + 13606471445

SPIE.org

Copyright @ 2015 , Society of Photo-Optical Instrumentation Engineers.

Copying of material in this book for internal or personal use, or for the internal or personal use of electronically through CCC Online at copyright.com. Other copying for republication, resale, advertising or promotion, or any form of systematic or multiple reproduction of any material in this book is prohibited except with permission in writing from the publisher. The CCC fee code is 0277-786X/15/\$18.00.

Printed in the United States of America.

Publication of record for individual papers is online in the SPIE Digital Library.

\section{SP|E. DIGITAL}

Paper Numbering: Proceedings of SPIE follow an e-First publication model. A unique citation identifier (CID) number is assigned to each article at the time of publication. Utilization of CIDs allows articles to be fully citable as soon as they are published online, and connects the same identifier to all online and print versions of the publication. SPIE uses a six-digit CID article numbering system structured as follows:

- The first four digits correspond to the SPIE volume number.

- The last two digits indicate publication order within the volume using a Base 36 numbering system employing both numerals and letters. These two-number sets start with $00,01,02,03,04$, $05,06,07,08,09,0 A, 0 B \ldots$. OZ, followed by 10-1Z, 20-2Z, etc. The CID Number appears on each page of the manuscript. 


\title{
Contents
}

\author{
$\checkmark$ Authors \\ vii Committee Page
}

\section{X-RAY AND GAMMA-RAY SYSTEMS I}

959502 Maximum likelihood source localization using elpasolite crystals as a dual gamma neutron directional detector [9595-1]

$959504 \quad$ Negative temporal cross covariance in Srl2:Eu [9595-23]

959505 Microsystem for remote sensing of high energy radiation with associated extremely low flux densities [9595-3]

959506 Measuring x-ray spectra of flash radiographic sources [9595-4]

959507 Auger compositional depth profiling of the metal contact-TIBr interface [9595-5]

959508 Design and optimization of a radiation detector for ground and spaced-based exposure [9595-6]

\section{X-RAY AND GAMMA-RAY SYSTEMS II}

959509 Detector blur associated with MeV radiographic imaging systems (Invited Paper) [9595-7]

9595 0A Quantitative criteria for assessment of gamma-ray imager performance [9595-8]

9595 OB Physical basis for signal separation for remote sensing of multiple high energy radiation sources [9595-9]

\section{PARTICLE SYSTEMS}

9595 OG Spatial response characterization of He-4 scintillation detectors [9595-14]

$95950 \mathrm{~J}$ Time gating for energy selection and scatter rejection: High-energy pulsed neutron imaging at LANSCE [9595-17]

\section{POSTER SESSION}

9595 OK Evaluation of a gamma camera system for the RITS-6 accelerator using the self-magnetic pinch diode [9595-18]

$9595 \mathrm{OL}$ Influence of tailed-current on UXO prospecting [9595-19]

9595 OM An improved RF circuit for Overhauser magnetometer excitation [9595-20]

9595 ON Stacked, filtered multi-channel X-ray diode array [9595-21] 
Proc. of SPIE Vol. $9595959501-4$

Downloaded From: https://www.spiedigitallibrary.org/conference-proceedings-of-spie on 26 Apr 2023 Terms of Use: https://www.spiedigitallibrary.org/terms-of-use 


\title{
Authors
}

Numbers in the index correspond to the last two digits of the six-digit citation identifier (CID) article numbering system used in Proceedings of SPIE. The first four digits reflect the volume number. Base 36 numbering is employed for the last two digits and indicates the order of articles within the volume. Numbers start with 00, 01, 02, 03, 04, 05, 06, 07, 08, 09, 0A, 0B...0Z, followed by 10-1Z, 20-2Z, etc.

\author{
Abbot, Kazim, 08 \\ Baker, Stuart A., 09, 0K \\ Barzilov, Alexander, 02 \\ Barrett, Harrison $\mathrm{H} ., 04$ \\ Bora, Vaibhav, 04 \\ Brown, Kristina K., 09 \\ Chen, Shudong, OL \\ Cirignano, L., 07 \\ Clarkson, Eric, 04 \\ Compton, S. M., ON \\ Conway, A. M., 07 \\ Danielson, Jeremy, 09 \\ Derosa, Pedro, 08 \\ Dutra, E. C., ON \\ Espy, Michelle A., 06 \\ Fastje, David, 04 \\ Fu, Haoyang, OL, OM \\ Furenlid, Lars, 04 \\ Gehring, Amanda E., 06 \\ Gignac, Raymond, OK \\ Gottesman, Steve, OA \\ Graff, R. T., 07 \\ Guckes, Amber, 02 \\ Guo, Xin, OM \\ Guss, Paul P., 02 \\ Haines, Todd J., 06, 09 \\ Hunter, James, 0J \\ Howe, Russell A., 09 \\ Jacoby, B. A., ON \\ Jain, V. K., 05, OB \\ Jana, Dilip, 08 \\ Jordan, Kelly A., OG \\ Keller, Kristi, OA \\ Kelley, Ryan P., OG \\ Kiefer, Mark L., OK \\ Kim, $\mathrm{H}, 07$ \\ Lutz, Stephen S., 09 \\ MacNeil, L. P., ON \\ Malik, Hans, OA \\ McKigney, Edward, OJ \\ Mendez, Jacob, 06 \\ Mitchell, Stephen E., 09 \\ Moir, David C., 06 \\ Morgan, Dane, 09 \\ Mukhopadhyay, Sanjoy, 02 \\ Murer, David, OG \\ Nelson, A. J., 07 \\ Nikolic, R. J., 07 \\ Otten, A., 05
}

Payne, S. A., 07

Raphaelian, M. L., ON

Ray, Heather, OG

Richards, J., OB

Saint-Jean, Dileon, 08

Sawyer, Lee, 08

Schirato, Richard, 0J

Schultz, Larry J., 09

Sedillo, Robert, 06

Shah, Kanai S., 04, 07

Shirwadkar, Urmila, 04

Shurter, Roger P., 06

Smalley, Duane D., 09

Stampahar, Thomas G., 02

Steinberg, Noah, OG

Swanberg, E. L., 07

Swift, Alicia, OJ

Temple, Brian, 0J

Volegov, Petr, 06

Voss, L. F., 07

Webb, Timothy J., 06, OK

Williams, Darnel, 08

Zhang, Linlin, OL

Zhang, Shuang, OL, OM

Zheng, Di, OM 
Proc. of SPIE Vol. $9595959501-6$

Downloaded From: https://www.spiedigitallibrary.org/conference-proceedings-of-spie on 26 Apr 2023 Terms of Use: https://www.spiedigitallibrary.org/terms-of-use 


\section{Conference Committee}

Program Track Chairs

Ali M. Khounsary, X-ray Optics, Inc. (United States) and Illinois Institute of Technology (United States)

Ralph B. James, Brookhaven National Laboratory (United States)

Conference Chairs

Gary P. Grim, Lawrence Livermore National Laboratory (United States)

H. Bradford Barber, The University of Arizona (United States)

Conference Program Committee

Stuart A. Baker, National Security Technologies, LLC (United States)

Patrick Feng, Sandia National Laboratories, California (United States)

Paul P. Guss, National Security Technologies, LLC (United States)

Khalid M. Hattar, Sandia National Laboratories (United States)

Ralph B. James, Brookhaven National Laboratory (United States)

Edward Steven Jimenez Jr., Sandia National Laboratories,

(United States)

Will E. Johns, Vanderbilt University (United States)

Michael J. King, Rapiscan Systems Laboratories (United States)

Edward A. McKigney, Los Alamos National Laboratory (United States)

Wondwosen Mengesha, Physical Optics Corporation (United States)

Frank E. Merrill, Los Alamos National Laboratory (United States)

Michael R. Squillante, Radiation Monitoring Devices, Inc.

(United States)

Session Chairs

1 X-Ray and Gamma-Ray Systems I

Daniel A. Lemieux, The University of Arizona (United States)

2 X-Ray and Gamma-Ray Systems II

Frank E. Merrill, Los Alamos National Laboratory (United States)

3 Target Diagnostics: Joint Session with Conferences 9591 and 9595

Gary P. Grim, Lawrence Livermore National Laboratory (United States)

4 Particle Systems

H. Bradford Barber, The University of Arizona (United States) 
Proc. of SPIE Vol. $9595959501-8$

Downloaded From: https://www.spiedigitallibrary.org/conference-proceedings-of-spie on 26 Apr 2023 Terms of Use: https://www.spiedigitallibrary.org/terms-of-use 